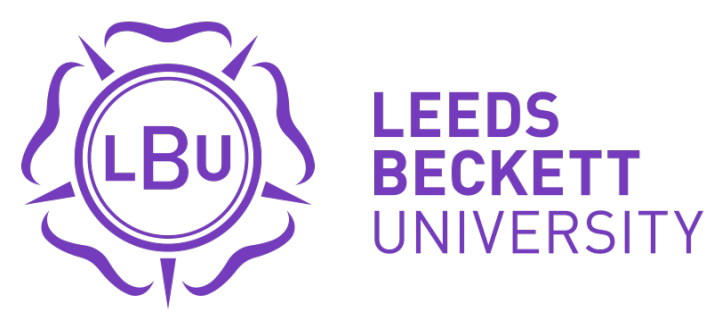

Citation:

Van Horssen, J (2016) International agency over local land: Mine expansion and industrial priorities in the Town of Asbestos, Canada. Jahrbuch fur Wirtschaftsgeschichte, 57 (1). pp. 9-28. ISSN 0075-2800 DOI: https://doi.org/10.1515/jbwg-2016-0002

Link to Leeds Beckett Repository record:

https://eprints.leedsbeckett.ac.uk/id/eprint/4313/

Document Version:

Article (Accepted Version)

The aim of the Leeds Beckett Repository is to provide open access to our research, as required by funder policies and permitted by publishers and copyright law.

The Leeds Beckett repository holds a wide range of publications, each of which has been checked for copyright and the relevant embargo period has been applied by the Research Services team.

We operate on a standard take-down policy. If you are the author or publisher of an output and you would like it removed from the repository, please contact us and we will investigate on a case-by-case basis.

Each thesis in the repository has been cleared where necessary by the author for third party copyright. If you would like a thesis to be removed from the repository or believe there is an issue with copyright, please contact us on openaccess@leedsbeckett.ac.uk and we will investigate on a case-by-case basis. 


\section{International Agency Over Local Land: Mine Expansion and Industrial Priorities in the Town of Asbestos, Canada Jessica van Horssen, University of Chester}

What happens to a resource community whose existence is entirely determined not just by the work they do, or the type of lives they choose to live, but rather by a faceless global industry, seemingly insatiable for its resource? What happens when that insatiable need suddenly stops? This paper will examine the town of Asbestos, Canada, which is the location of what was once the world's largest opencast asbestos mine, the Jeffrey Mine. Central to the community's economy, asbestos is a fibrous mineral that is found entwined in rock, and can be woven into, or added to, a seemingly-infinite amount of goods to make them fireproof and more durable. Indeed, asbestos can withstand heat up to $3000^{\circ} \mathrm{F}$. Historically, Asbestos was a single resource community, with the mine located at the centre of town, and operated by the American Johns-Manville Company (JM). As townspeople framed their lives around the mine - with residential and commercial streets branching from its crater-like ${ }^{1}$ presenceglobal markets significantly impacted how they did so throughout the "boom years" of the asbestos industry, 1918-1983.

The Jeffrey Mine produced 85 percent of the world's supply of the fireproof mineral through much of the $20^{\text {th }}$ century largely due to the unique nature of the land at what was to become Asbestos. While most asbestos deposits are found in linear veins shooting through layers of rock, often requiring several mines to access it all, the deposit at the town of Asbestos was circular, and created a rounded knoll absolutely full of the mineral. This meant that only one mine was needed to extract the valuable mineral, but it also meant that the people of Asbestos had built their community literally on top of a massive ore deposit. While the industry relied on the local population to extract the mineral, that very same local population also hindered market growth through the sheer fact of their presence on the land surrounding the mine.

The nature of open cast mining is that it never remains stagnant, and the pit must always be expanded in order for workers to access more of the mineral. However, because the town of Asbestos was built around the Jeffrey Mine, this meant that each time JM expanded the limits of the pit, part of the community was consumed by it. Through analysing the 11 Jeffrey Mine expansions that occurred from 1928-1980, this paper will examine the fundamental local-

\footnotetext{
${ }^{1}$ The community often looked at the mine as a crater. For example, please see Procès-verbal, La ville d'Asbestos, 21 January 1981, p. 171
} 
global dilemma present in the town of Asbestos: international markets dictated when the Jeffrey Mine needed to be expanded, geology dictated where it should expanded, and the local population-so crucial to meeting these market demands and so knowledgeable of the mineral itself - needed to be close enough to do the required labour for the expansion and extraction of raw asbestos, but they needed to get out of the way of it.

From 1928-1980, Asbestos became a "rolling" mining community. Townspeople moved homes, businesses, and other local facilities and infrastructure away from the edges of the Jeffrey Mine, but not far enough away that their properties were safe from future pit expansion. Johns-Manville was responsible for deciding when and how the Jeffrey Mine would expand, with little consideration for the local population: global markets and rising profits were what mattered most. While the community was French Canadian, JM employed Anglophone engineers and geologists to lead these expansions, removing any real agency from local workers or government. In examining this process, this paper will show how the tensions caused by this local-global dilemma were negotiated and experienced in the community. In doing so, it will trace the development of a strong local identity that was linked to the global asbestos industry that dictated the development of their land, as well as the resilience of mining communities in the face of adapting to day to day realities beyond their control.

Being close to both work and civic life, the homes and businesses surrounding the Jeffrey Mine were actually some of the most desirable in Asbestos. This desirability contributed to townspeople's willingness to accommodate the growing needs of the industry by dismantling their homes and moving them away from the edges of the mine. By tracing the local expansion of the Jeffrey Mine, this paper will also show the rise and fall of the global asbestos industry, so connected to the community that housed the largest mine in the world. From 1928, when this region of Canada produced 224,701 tons of raw asbestos out of the global 345,000 tons, to 1980, when it produced 1,004,025 tons out of the global 4,699,300 tons, it was clear that asbestos was big business, and the community of Asbestos was central to it.

The nature of asbestos mining meant that an open pit could be mined for decades before it required expansion. The rapidity in which the Jeffrey Mine reached its limits was largely determined by global demand for the mineral, as new uses for asbestos were developed each 
year. While it certainly was inconvenient to move your home every 5-10 years, locally the Jeffrey Mine was referred to affectionately as "the mine that ate the village," and mine expansion usually meant the industry — and therefore the community—was booming. This was a place focused on the future, not the past, and it was prepared to make any sacrifice it needed to in order to guarantee success. This became especially important as the industry began to crumble as reports of the negative health effects of asbestos became well-known in the western world. However, at the start of the $20^{\text {th }}$ century, the asbestos industry was beginning to boom, and the American Johns-Manville Co. helped facilitate an industrial revolution to the natural phenomenon that was the land at Asbestos.

\section{Positive Boom Years}

The Johns-Manville Co. ${ }^{2}$ took full control of the Jeffrey Mine in 1916, just as the asbestos industry was beginning to boom because of the mineral's numerous wartime uses, including being used in soldier's uniforms to protect them against fire on the front. JM was historically a manufacturer of materials used in the construction industry, and the fireproof mineral that could strengthen most products it was added to was central to the company's growth. In fact, by 1898 , the majority of the asbestos workers extracted from the Jeffrey Mine went directly to JM factories in the United States, and the company had become the largest manufacturer of asbestos-based products in the world. ${ }^{3}$ Investing in an asbestos mine- and an asbestos mining community - thus made good business sense for JM, especially as the company rightly anticipated the profits that could come from post-war reconstruction.

Johns-Manville brought a "bigger is better" mentality to this small mining community, as well as a promise of permanence, and the local population quickly grew around the mine as the industry boomed in the interwar years. Asbestos was not the only town in the region that mined the mineral, but at the start of the $20^{\text {th }}$ century, it was among the most undeveloped and unprofitable. This was largely because the companies that had operated it in the past lacked the geological knowledge to access the unusual deposit at its full potential. ${ }^{4}$ This was not a

\footnotetext{
2 The company was originally named the H.W. Johns-Manville Co., and did not officially become "Johns-Manville" until 1930. However, because of its more recognizable name and because most studies of the industry refer to it as JM, this paper will exclusively refer to it as Johns-Manville for consistency.

${ }^{3}$ The Canadian Mining Review, vol. 12 (January 1893), p. 4.

${ }^{4}$ Indeed, the first owners of the Jeffrey Mine went bankrupt in 1892 despite the rise in demand for the mineral. Jessica van Horssen, A Town Called Asbestos: Environmental Contamination, Health, and Resilience in a Resource Community (Vancouver: University of British Columbia Press, 2015). (Forthcoming)
} 
problem for JM, as the company had the funds to hire geologists and engineers who could understand the land at Asbestos in ways previous companies and even the local population could not. American money and connections revolutionized the land in Asbestos, and the Jeffrey Mine quickly became an efficient, quasi-natural machine, with spiralling benches winding from the bottom to the top, steam shovels, derricks, and, soon enough, a train transporting ore from the bottom of the pit to the nearby Grand Trunk Railway line. ${ }^{5}$

Johns-Manville brought a "bigger is better" mentality to this small mining community, as well as a promise of permanence that previous mine owners could not guarantee. The local population quickly grew around the mine as the industry boomed in the interwar years, and both men and women found employment there. Everything — and everyone - in Asbestos became oriented towards, and devoted to, the mine and industry, which is often a precarious situation for single industry resource communities. ${ }^{6}$ Even for the merchants who operated local stores, JM provided the necessary salaries for local customers: the Jeffrey Mine was the reason for being in Asbestos, and without its continued development, the community would collapse. This devotion to, and perhaps even this faith or trust in the mine took root and changed as the community was swept through the various booms and busts of the global industry.

This international market growth directly led to the necessary growth of the Jeffrey Mine itself, as with JM's connections, it had quickly become central to the global industry. The company raised extraction levels at the pit to feed its vast network of processing plants throughout the United States, and these new rates rapidly consumed the land that separated the edges of the mine from the community. In 1923, Asbestos town council had given the company permission to "move" one of the major roads in the community by 66 feet to facilitate easier shipment of raw asbestos from the Jeffrey Mine to international processing plants, as local residents were getting in the way. The local government agreed to this move because it wanted to make industrial development of the land as easy as possible for JM, as

\footnotetext{
${ }^{5}$ Environmental Historian Richard A. Rajala has written about the timber industry transforming forests into giant open air factories, and his perspective on the industrialization of natural resources inspires this piece. Richard A. Rajala, Clearcutting the Pacific Rainforest: Production, Science, and Regulation (Vancouver: UBC Press, 1998), p. 30.

${ }^{6}$ For example, please see Michael A. Amundson, Yellowcake Towns: Uranium Mining Communities in the American West (Denver: University Press of Colorado, 2004), Charlie Angus and Brit Griffin, We Lived a Life and then Some: The Life, Death, and Life of a Mining Town (Toronto: Between the Lines, 1996), Larry Lankton, Cradle to Grave: Life, Work, and Death at the Lake Superior Copper Mines (Oxford: Oxford University Press, 1991), Anthony F.C. Wallace, St. Clair: A Nineteenth-Century Coal Town's Experience with a Disaster-Prone Industry, $3^{\text {rd }}$ ed. (New York: Alfred A. Knopf, 1987), Michael A. Amundson, Yellowcake Towns: Uranium Mining Communities in the American West (Denver: University Press of Colorado, 2004).
} 
the industry was "so essential to the life and interest of the local community." Local residents were also in danger of flying rocks, as many family homes were located on this road that wound around the edges of the mine. The "moving" of a road was phase 1 of JM's initial plans for development and expansion; phase 2 was coming quickly.

In 1927, the population of Asbestos had grown to over 3,000 people, with the vast majority of residents employed at the Jeffrey Mine. The physical limits of the community needed to grow alongside this population, and the provincial government granted the town's request to extend the borders of Asbestos by 17,588 feet. By this time, JM had become the community's largest landholder after owning the Jeffrey Mine for just over ten years, and this distinction afforded it a significant amount of power over municipal affairs. ${ }^{8}$ As soon as the provincial government gave the town of Asbestos permission to extend its boarders to accommodate a growing population, JM requested 55 acres of the town's total 800 acres in order to expand the Jeffrey Mine. ${ }^{9}$ This was, of course, in addition to the company supplying electricity to the community.

Because it was an open pit, there were limits to what workers could reasonably and safely extract from the Jeffrey Mine: by 1928, the Jeffrey Mine resembled a steep inverted cone, rather than the spiralling circle it was soon after JM took over operations. Landslides were common, and extraction levels were shrinking because of a lack of physical space. Driving this landscape change was the fact that prices for asbestos were rising internationally, and Canada provided 85 percent of the global supply of the mineral: this was a massive industry and JM required unobstructed freedom to exploit the land at Asbestos, located in "the most important asbestos producing region in the world."10

\footnotetext{
7 “si essentiel à la vie et l'intérêt de la communauté locale," English translation by author, Procès-verbal, La ville d'Asbestos, 13 November 1923, p. 447.

${ }^{8}$ Procès-verbal, La ville d'Asbestos, 11 August 1927, p. 151, and 31 December 1928, p. 229

${ }^{9}$ Procès-verbal, La ville d'Asbestos, 27 April 1927, p. 137

${ }^{10}$ Asbestos: Its Sources, Extraction, Preparation, Manufacture, and Uses in Industry and Engineering (Berlin: Becker and Haag, 1928), p. 17
} 


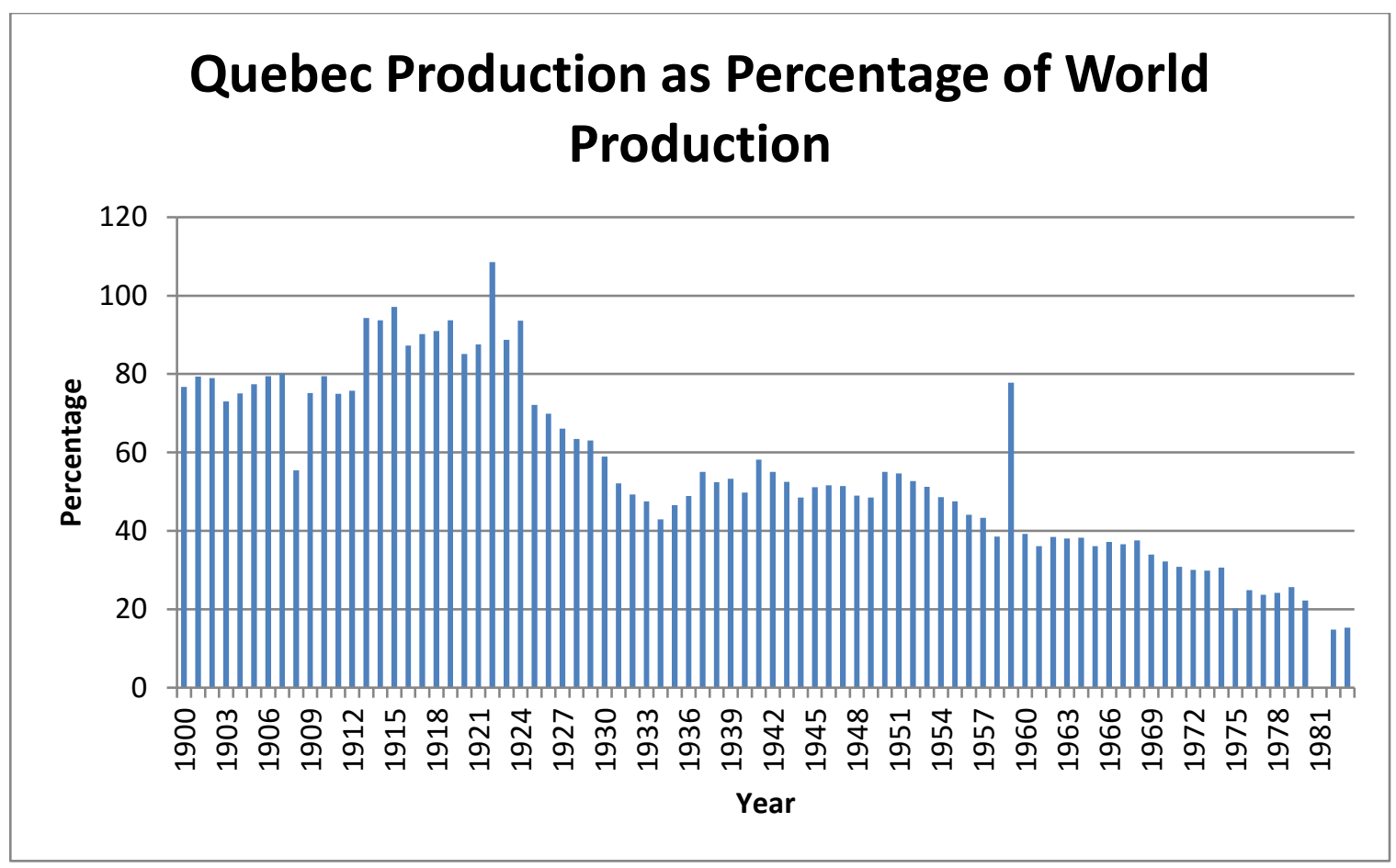

Quebec Asbestos Production as a Percentage of World Production of Asbestos, 1900-1983 ${ }^{11}$

For the most part, the community could see that mine expansion was the logical next step.

Workers did not want to continue working in an unsafe environment, and JM had promised to build new homes for all those whose houses would be destroyed by the pit expansion. These new homes would be located further away from the edges of the mine, and equipped with all the modern conveniences residents of Asbestos had yet to experience, including electricity and indoor plumbing. ${ }^{12}$ This was the type of municipal investment townspeople had been waiting for, as the community was transformed from a small mining town to an industrial centre. Of course, a major issue that nobody seemed to take notice of at the time was that while residents had owned their homes at the edge of the pit, they would not own these new ones. Instead, they would rent them from the company, making them more mobile and less legally_if not emotionally_attached to one specific place or building.

\footnotetext{
${ }^{11}$ The Quebec data is based on data provided by the Reports on Mining Operations (1898-1936) and on the Mining Industry of the Province of Quebec (1937-2000) (http://www.mern.gouv.qc.ca/mines/desminesetdeshommes/index.jsp\#annexe), compiled by Marc Vallières, and I have converted the short tons on the list to metric tons to more easily compare with the world data, which was provided by the United States Geological Survey, Circular 1298, Robert L. Virta, "Worldwide Asbestos Supply and Consumption Trends from 1900 through 2003, 2006 (http://pubs.usgs.gov/circ/2006/1298/c1298.pdf) p. 32-34. There is a discrepancy in the figure for 1922, which reads as $108 \%$ of global supply, which is obviously incorrect, although I have found no data to suggest which number is wrong, so I have left it as is.

${ }^{12}$ Réjean Lampron, Marc Cantin, and Élise Grimard, Asbestos: Filons d'Histoire, 1899-1999 (Asbestos: Centenaire de la ville d'Asbestos, 1999), p. 140.
} 
Despite this underlying issue, JM quickly and efficiently destroyed these old homes as well as the entire original section of town, known to the local population as the "nerve centre" of the community. ${ }^{13}$ This was the first in a long line of largescale mine expansion in Asbestos, and amid promises of the company building a new commercial centre, Johns-Manville quickly and efficiently began to tear down a significant portion of the community, and put up the first barbed wire fence between the edges of the mine and town roads.

For most in the community, it seemed that what was destroyed didn't matter: what was important was that mine expansion ensured the town had a purpose, citizens would have jobs, and everyone would prosper. The destruction of the original section of town reinforced the idea that Asbestos was a place with a future, not a past, and the local population had to let go of the original bones of the community if it wanted to succeed, which it did. Not even the Great Depression hitting the community at the start of JM's expansion efforts seemed to shake this conviction for most of the local population.

The majority of townspeople worked at the Jeffrey Mine, or were closely connected to someone who did, and they believed in Johns-Manville with the same fervour that they believed in the Jeffrey Mine, even in the midst of the Depression. Because of its close ties to the automotive and manufacturing industries, JM was forced to shut down its operations between May 1932 and April 1933. This was a devastating time for the community of Asbestos, and many had to rely on government aid to feed their families during this period of economic crisis. However, the temporary mine closure taught the local population a valuable lesson on what life would be like in the community if JM was not given free reign to develop the mine as it wanted to. Townspeople developed a fresh understanding of the fact that this was the largest - if not the only_-source of revenue in the town, and their faith in JM and in the Jeffrey Mine to bring them out of the Depression shaped future decisions they made locally about the use and governance of their land.

There remained a small, yet vocal, segment of the town of Asbestos that disagreed with giving JM such great power: the community's merchant class. Although their revenue was tied to the wages the majority of townspeople received from Johns-Manville, local merchants

\footnotetext{
${ }^{13}$ Le Citoyen. 28 December 1974, p. 42. This phrase was also used in a 1967 article on the expansion of the Jeffrey Mine: W. Gillies Ross, "Encroachment of the Jeffrey Mine on the Town of Asbestos, Quebec," Geographic Review, v. 57, n. 4 (1967).
} 
refused to give the company carte blanche when it came to community development. Out of the over 3,000 people in Asbestos at the start of the 1930s, only eight officially protested the mine's expansion. All of these eight were local merchants whose businesses would be affected by the reorganization of roads and neighbourhoods the expansion required, especially after the Depression hit and Jeffrey Mine workers could not pay their tabs. These merchants believed that in granting JM permission to destroy the centre of Asbestos, town council was acting in the interest of Johns-Manville, not the community. ${ }^{14}$ Despite this small faction disagreeing with the plans for mine expansion during a time of economic instability, when the mayor passed the matter onto the province for a final verdict, the government wholeheartedly agreed to it and passed a Bill of Expropriation to overrule any local protest.

Because of its previous economic buoyancy, the government believed that the asbestos industry would be one of the major factors in the province's emergence from the Depression, and it could not be stopped. Even if the mine destroyed segments of the community, it was simply far too important to the provincial economy to be limited by space. By the end of 1933, the global demand for asbestos had increased by 71 percent, production had risen by 29 percent, the Jeffrey Mine had been reopened, and local workers had returned to their jobs: ${ }^{15}$ it seemed like the sacrifice to both land and heritage had indeed been worth it, and townspeople had learned to trust JM's expertise when it came to both local land and international markets.

Extraction levels at the Jeffrey Mine did not reach pre-Depression levels until the industry boom that came with the Second World War, but local employees worked an average of 58 hours a week by 1935, and could once again support their families. The hard years of the Depression were soon forgotten as Canadian production levels rose sharply in the second half of the 1930s, with 247,954 metric tons of raw asbestos being extracted in 1936, worth $\$ 9,958,183$, and 337,443 metric tons worth $\$ 14,505,541$ in $1937 .{ }^{16}$ While only five percent of the raw fibre was processed in Canada, most of the rest went directly to JM's large network of processing plants in the United States.

These high levels of production once again contributed to the Jeffrey Mine becoming unworkable, with its sides sloping sharply up, causing landslides and delays. JM appealed to

\footnotetext{
${ }^{14}$ Le Citoyen, 28 December 1974, p. 70.

${ }^{15}$ Oliver Bowles and B.H. Stoddard, “Asbestos,” Minerals Yearbook 1934, Kiessling, O.E., ed. (Washington: United States Government Printing Office, 1934), p. 1014.

${ }^{16}$ The Canadian Mining Journal, February 1938, p. 65.
} 
the municipal council in 1938 to expand its operations onto 14 undeveloped lots at the edge of the Jeffrey Mine, and the local government immediately granted the request. ${ }^{17}$ Local council also purchased 21 new lots of land from neighbouring farmers on which it could expand community living space as JM enlarged the Jeffrey Mine. ${ }^{18}$ This second expansion set a pattern in Asbestos that saw the town limits grow alongside those of the mine, all because of international market demand. By 1939, the Jeffrey Mine had become the largest chrysotile asbestos mine in the world, ${ }^{19}$ and it remained so for much of the $20^{\text {th }}$ century because of the local commitment to industry growth over community land. At the start of the Second World War, workers at the Jeffrey Mine extracted an immense 3 million tons of rock and stripping each year from the 300 foot wide, 510 foot deep pit.

Industry magazines like the Canadian Mining Journal fawned over the impressive operations at Asbestos, noting in 1939 that your first impression of the Jeffrey Mine was "one of size. Here is an operation that handles great quantities of material, and uses mammoth machines in the process. [Here] is the largest power shovel in Canada; along its levels run standard locomotives hauling trains of cars...Yet as one stands on the high side of the pit looking down, these great machines look like toys in that immensity of space.” ${ }^{20}$ There was real excitement surrounding the asbestos industry — and, in particular, the town of Asbestos — at the end of the 1930s, and its continuation seemed certain. Townspeople had yet to realize the effects this would have on local land, and the central role they were beginning to play in the global industry encouraged a real sense of pride in Asbestos.

The mid- $20^{\text {th }} \mathrm{C}$ was seen by industry leaders as the "Asbestos Age," and the US Mineral's Yearbook described it as being "indispensable to modern life" at the outbreak of the Second World War. ${ }^{21}$ Local labour, combined with American management, had made the Jeffrey Mine both a natural and technological phenomenon, and this international status further solidified the local devotion to the mine, the company, and the industry. This devotion was capitalized upon by the international industry during the Second World War. Shifts at the Jeffrey Mine ran 24 hours a day, seven days a week to ensure production levels met the

\footnotetext{
${ }^{17}$ Procès-verbal, La ville d'Asbestos, 30 September 1938, p. 158.

18 Procès-verbal, La ville d'Asbestos, 3 January 1939, p. 182, and Procès-verbal, La ville d'Asbestos, 3 April 1939, p. 210.

${ }^{19}$ RC Rowe, "Mining and Milling Operations of the Canadian Johns-Manville Company Ltd. at Asbestos, PQ," The Canadian Mining Journal, April 1939, p. 185.

${ }^{20}$ Ibid, p. 194.

${ }^{21}$ Oliver Bowles and K.G. Warner, “Asbestos,” Minerals Yearbook, Herbert Hughes, ed. (Washington: United States Government Printing Office, 1939), p. 1309.
} 
demands of the wartime and postwar market. Indeed, the majority of able bodied men living in Asbestos did not enlist in the military to serve in Europe, but instead stayed at home to work in the mine. Canadian asbestos production rose by more than 100,000 tons during the war partly because of these local efforts. ${ }^{22}$

Asbestos-containing products, so popular in the First World War, became even more so during the 1940s as new technologies of both war and peace relied on the mineral for strength, durability, and protection from fire. The increase in extraction levels at the mine meant that the pit had once again come close to its physical limits within the town of Asbestos. In 1947 the Quebec industry exported 10,785,189 tons of fibre valued at $\$ 438,356,805$ and by 1948 , the Jeffrey Mine had grown to 3,200 feet long by 2,800 feet wide. ${ }^{23}$ Workers at the mine now extracted between 19,000 and 22,760 tons of rock every 24 hours, compared to the 389,688 tons they had extracted per annum just ten years earlier. ${ }^{24}$

A lengthy five month strike at the start of 1949 halted both local and global production of the mineral. When workers returned to the Jeffrey Mine in the spring, they were confronted with the fact that their local labour dispute had left the global industry with a shortage of approximately a quarter of a million tonnes of asbestos. ${ }^{25}$ While the Jeffrey Mine was only one of several Canadian asbestos mines, its sheer size and connections to the lucrative American market meant that its workers exercised significant control over the flow of raw asbestos internationally. Indeed, despite the strike, by 1950 Canada still controlled 61 percent of the global asbestos industry, worth $\$ 64$ million. ${ }^{26}$ Because of the shortage, the market price for raw asbestos rose, and JM raised production targets at the Jeffrey Mine so it could maximize profits during this window of opportunity.

\section{Changing Opinions Both Locally and Globally}

\footnotetext{
${ }^{22}$ This figure refers to American tons, which are 2,000lbs. One of these new products was asbestos sheeting, invented in Britain, which was able to withstand extremely high temperature and pressure, suitable for both fighter jets and commercial airlines. Oliver Bowles and Dorothy I. Marsh, "Asbestos," Minerals Yearbook, E.W. Pehrson and C.E. Needham, eds. (Washington: United States Printing Office, 1944), p. 1478.

${ }^{23}$ H.R. Rice, "The Asbestos Industry in Quebec," The Canadian Mining Journal, October 1948, p. 148.

${ }^{24}$ Ibid.

${ }^{25}$ G.W. Josephson and F.M. Barsigian, “Asbestos,” Minerals Yearbook 1949, Allen F. Matthews, ed. (Washington: United States Printing Office, 1951), p. 139, and The Canadian Mining Journal, August 1949, p. 54.

${ }^{26}$ United States Geological Survey 1950 (Washington: United States Printing Office, 1951), p. 6.
} 
Raising production levels at a mine that had already reached its physical limits was a bold move. Workers extracted on average three times more asbestos at the Jeffrey Mine than their Canadian counterparts did, and landslides again became common. It was clear to everyone in the community that another expansion was necessary, but attitudes towards JM had changed during the lengthy strike of 1949, and the local population was less willing to sacrifice its land for the American company's profits. Sensing this shift in local dynamics, instead of expanding the edges of the mine onto community land, JM instead developed a block-caving system that established shaft mines around the perimeter of the mine. These shaft mines allowed workers to extract a significant amount of raw asbestos without significantly infringing on municipal land. In fact, the only community members who voiced complaints about this new method were again local merchants, who were concerned the shafts would blur the boundaries between liveable space and workable space in the community too much. Indeed, the first shafts the company built lined Rue Bourbeau, which was the main commercial street in Asbestos. By 1952, each block was 200 square feet, had crushing plants 816 feet below ground, and loading facilities 950 feet down. ${ }^{27}$ These efforts helped raise Canadian asbestos production from 61 percent in 1950 to 70 percent by $1952 .{ }^{28}$

Rising production levels at the Jeffrey Mine helped workers become the highest paid miners in Canada during the 1950s. It also signalled to townspeople that despite the shaft mines surrounding the pit, the company would need to significantly expand its operations in the near future. The editor of the local paper wrote about this eventuality in 1956, stating that the global industry's demands on the land in Asbestos meant that soon enough, the Jeffrey Mine will have consumed the entire community, and residents would be displaced to neighbouring towns due to a complete lack of liveable space. ${ }^{29}$

Johns-Manville did not attempt to pacify local fears concerning future mine expansion. In fact, when it submitted an application to Asbestos Town Council at the end of the 1950s for a gradual, yet massive mine expansion, it also laid off 120 of its shaft mine employees because of new extraction technologies making them redundant. ${ }^{30} \mathrm{JM}$ also cautioned town council against purchasing additional land for the community to grow onto once the expansion had

\footnotetext{
${ }^{27}$ This information was taken from a USGS report on a 1952 visit to Asbestos to survey operations. United States Geological Survey 1952 (Washington: United States Printing Office, 1953), pp. III-2.

${ }^{28}$ Canadian Mining Journal, February 1952, p. 106.

${ }^{29}$ Le Citoyen, 26 July 1956, p. 2.

${ }^{30}$ Le Citoyen, 25 July 1958, p. 1 and 17 April 1959, p. 1.
} 
been completed, as it anticipated needing less, not more, employees in the future because of these new technologies. The company was not invested in the community of Asbestos, but rather its main natural resource, and it would not let sentiment inhibit profits.

In a drastic shift from established practice, local residents — not just the local merchantsbegan to refuse to sell their property near the mine's edges to JM. If townspeople did not see direct benefits from the company's expansion onto community land in terms of stable jobs and wages, they would prevent it in any way they could. In reality, there was little community members could do to limit the Jeffrey Mine's growth: JM appealed for help to the provincial government in 1964, which passed another Bill of Expropriation. ${ }^{31}$ The industry was too important to the provincial and federal economy to limit its growth, and the government was not willing to challenge JM on its managerial practices as long as it was gaining substantial tax revenue from the company.

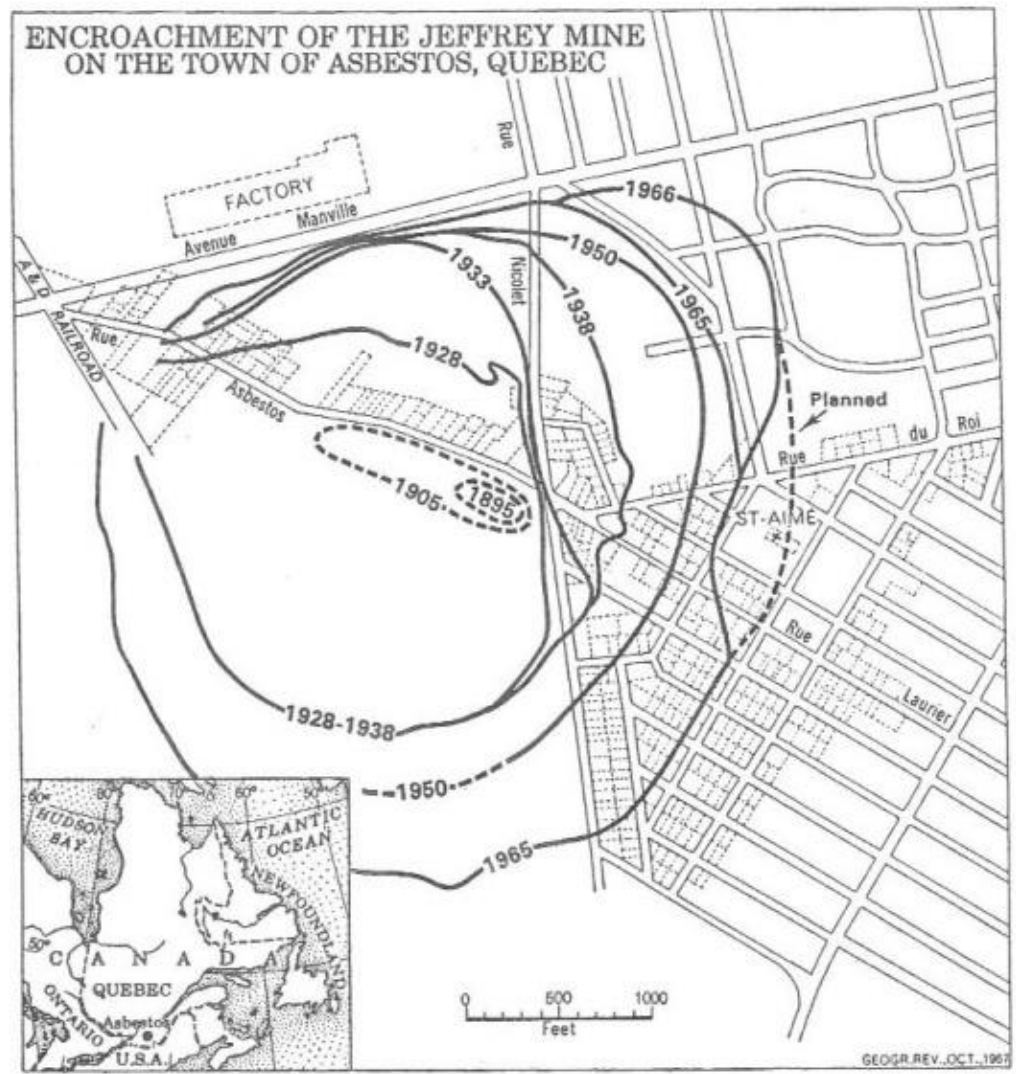

Map of Asbestos showing the past and planned expansions of the Jeffrey Mine, $1967^{32}$

\footnotetext{
${ }^{31}$ Le Citoyen, 30 January 1964, p. 1.

${ }^{32}$ W. Gillies Ross, "Encroachment of the Jeffrey Mine on the Town of Asbestos, Quebec," Geographic Review, vol. 57, no. 4 (1967), p. 529.
} 
The inevitable expansion of the Jeffrey Mine was something most townspeople accepted, but local merchants were once again concerned about what it would mean for their businesses. A group of them appealed to the provincial government to reconsider the Bill of Expropriation on the grounds that their profits would be affected by the disruption the project would cause. However, the industry was worth over $\$ 148$ million to the province, and JM had assured the government its planned expansion of the Jeffrey Mine would be worth over $\$ 20,000,000 .^{33}$ The merchants' complaints were again dismissed, and the expansion went ahead, first consuming the main church in the community, then the main commercial district.

By 1967, 250 buildings and 54 percent of the town centre had been consumed by the Jeffrey Mine. ${ }^{34}$ The local population could no longer recognize its community, but through working at the Jeffrey Mine, they supplied the global industry with over 600,000 tons of raw asbestos each year. ${ }^{35}$ Looking favourably on what JM had done to local land in its quest for more profit, the Canadian Mining Journal declared the community to be an impressive "industrial complex," and the "Free World's Largest Asbestos Producer," which had gotten rid of all the tired old buildings that used to be present in the town. ${ }^{36}$

Local land had indeed become part of a massive industrial complex, but what the journal failed to acknowledge were the effects this had on the local population living around the giant mine in the centre of town. By 1968, local residents began complaining that they were forced to "dine on dust and noise" because of the expansion, and they lobbied town council to establish a 1,000-foot buffer zone between the edges of JM property and community land. ${ }^{37}$ With the help of JM funds donated for community development, council established this buffer zone and constructed a 200 foot long wall to restrict mine activities from impacting community life. This was a first in Asbestos, which had historically embraced the blurred lines between the mine and community land, and it demonstrated the real struggles the local population had keeping up with the global demand for the mineral that gave the town its name. Although employment at the Jeffrey Mine was not significantly rising, Asbestos had

\footnotetext{
${ }^{33}$ Hansard. Journal des débats de l'Assemblée législative, 27e législature, $3^{\mathrm{e}}$ session (14 janvier 1964 au 31 juillet 1964), Le vendredi 19 juin 1964 - Vol. $1 \mathrm{~N}^{\circ} 96$.

${ }^{34}$ W. Gillies Ross, "Encroachment of the Jeffrey Mine on the Town of Asbestos, Quebec," Geographic Review, vol. 57, no. 4 (1967), p. 534.

${ }^{35}$ Canadian Mining Journal, May 1967, p. 45.

${ }^{36}$ Ibid.

37 “[n]ous en avons soupé de la poussière et du bruit," English translation by author, Le Citoyen, 23 April 1968, p. 1.
} 
run out of housing for its population, with a significant amount of homes being destroyed by the expansion.

Town council had to appeal to the provincial housing association for help in building new homes to house local family, and it was a constant struggle to keep up with JM's activities with the balance of land use that had previously been established by the company and community now lost.

By examining the mine expansions in Asbestos, we can see an interesting shift occurring. In the early "boom" years of the asbestos industry, even during the Depression, the majority of local residents supported the idea that the town of Asbestos had a future, not a past, and everything in the community needed to be oriented towards this future. At the beginning of the 1970s, after their homes and businesses had been lost several times to JM's expansion efforts, and when the negative health effects of the mineral became widely known and the industry began to collapse, the local belief in this future was profoundly shaken. Townspeople quickly became aware that they were facing a crisis much different in nature than the Depression, and suddenly, Asbestos only had its past to cling to.

Johns-Manville knew the industry was in trouble during the 1970s - the company was in serious financial trouble too due to occupational health lawsuits filed against the company by its American workers - and officials attempted to get as much asbestos out of the Jeffrey Mine as they could before the industry completely collapsed. Although profits and demand for asbestos were dwindling, the global industry was still worth over $\$ 210$ million by 1972 , and JM set yearly extraction levels at the Jeffrey Mine to reach 700,000 tons by 1975, even as the company began laying off employees by the hundreds. ${ }^{38}$ This was an incredible target, and if achieved, would completely consume the town of Asbestos. Indeed, that same year JM informed 160 local residents that they had to move their homes in order to accommodate mine expansion, prompting the local paper to write, "But where can they go?"39

Homes were already at risk of sliding into the pit, roads extending from the pit into the community were twisted and torn up as the Jeffrey Mine quickly, aggressively, and noisily expanded into the town. Rocks flew out of the mine and throughout the community as JM

\footnotetext{
${ }^{38}$ Canadian Mining Journal, February 1972, p. 139.

39 “Mais, pour aller où?" English translation by author, Le Citoyen, 15 April 1975, p. 3.
} 
increased blasting schedules and became more ambitious and extreme in its activities, and town council began closing key streets to ensure community safety. ${ }^{40}$ This was a community—and industry—in crisis.

By 1977, townspeople had started describing JM's activities at the Jeffrey Mine as "acts of vandalism," as rocks continued to be blasted into the community from the pit, putting the local population at risk, especially as the 1,000 foot buffer zone that council had previously established was destroyed by mine development. ${ }^{41}$ Increased production at the mine had increased its size to 6,500 feet from east to west, 6,000 feet from north to south, and 1,000 feet deep. As the company put its plans in motion to consume the land 200 locally-owned buildings were on, townspeople appealed to local council to do something to establish a safe distance between the community and the "cratère d'exploitation" the mine had become by 1981.42

It is significant to note that at the height of the western world's awareness of the dangers the mineral posed to human health, the people of Asbestos, who lived and worked beside the largest asbestos mine in the world, were mainly concerned with protecting their homes from mine expansion, not their children from asbestos-related disease. Much of this was because JM-funded doctors had lied to local residents about the effects of asbestos on their health from the beginning of the company's ownership of the mine, and this had a lasting impact on the way townspeople understood asbestos-related disease. Furthermore, as a community entirely dependent on the industry, the people of Asbestos knew it was the issue of health that was making it unstable. Keeping silent on this issue would perhaps help sustain the global industry and the local economy, but only if it did not cost townspeople their community.

Local silence on the health effects of asbestos did not prevent the industry from crumbling and JM from declaring bankruptcy in 1982 due to the significant number of occupational health lawsuits it faced in the United States. The last time an owner of the Jeffrey Mine had declared bankruptcy was in 1892 with William H. Jeffrey, who had discovered the deposit, but had not fully understood it. The company sold the Jeffrey Mine to a group of its Canadian executives and left Asbestos in 1983 as the community began a period of instability and

\footnotetext{
${ }^{40}$ Le Citoyen, 28 January 1975, p. 4.

${ }^{41}$ Procès-verbal, La ville d'Asbestos, 18 May 1977.

42 “working crater," translation by author, Procès-verbal, La ville d'Asbestos, 21 January 1981, p. 171.
} 
uncertainty it has yet to emerge from. While activities at the Jeffrey Mine had recovered following this first bankruptcy as new owners brought fresh expertise to its operations, the shift in ownership during the 1980s was significantly different. Understanding this difference when reporting on the company's bankruptcy, the local paper articulated townspeople's concerns when it reported that without JM, Asbestos would collapse. ${ }^{43}$

Johns-Manville had been the industry's leader for decades, and no other company had the money or connections required to sustain a positive image of the mineral. Expansion plans into the town were halted by the mine's new owners as the provincial and federal governments gave millions in subsidies and sought new markets in the developing world to sell Canada's raw asbestos to. The population of Asbestos began to bleed out, shifts became limited to four or six months a year, and extraction levels dropped so sharply due to the diminished market demand for the dangerous mineral that expansion was not necessary for almost 20 years.

\section{Conclusion}

While the industry in Asbestos continued until 2012, this was only because of these government subsidies and the local population's sheer determination to prevent the community from collapsing. This is when we see a real crisis in the community of Asbestos develop, as it suddenly became a place without a future, and the past suddenly became the only think townspeople had to cling to. As willing or resigned as the local population was to allow mine expansion, they were powerless against the global collapse of the asbestos industry because of the mineral's harmful effects on human health.

The final proposal for the Jeffrey Mine to be expanded was proposed in 2010 by the conglomerate that owned the pit until its final closure and had a much different local reception than the resistance townspeople put up during the 1970s. This expansion was the community's lifeline. Each of the previous eleven mine expansions in Asbestos had signalled to townspeople that business was booming and their jobs were secure. Although they did not always agree with the community destruction that came with these expansions, that was the positive constant throughout JM's history in the town.

\footnotetext{
${ }^{43}$ Le Citoyen, 10 August 1982, p. 2.
} 
The proposed expansion in 2010 was for different reasons. This was a last-ditch effort to get as much asbestos out of the Jeffrey Mine as the company could before the Canadian industry collapsed due to international pressure. New markets in places like China, India, and Mexico were hungry for the mineral for many of the same reasons the western world had historically desired it, but also because asbestos had become a relatively cheap commodity in global markets because of the risks it posed to human health. In countries without strict occupational health regulations, it remained a viable additive to building materials and domestic goods, despite the harm it did to the local population.

While their absolute dependence on the industry — and therefore this final expansion - meant that nobody in Asbestos protested the proposed expansion, national and international antiasbestos lobby groups did. These groups often consisted of people who were suffering from asbestos-related disease from working with the mineral in other industries, and the family members of those who had died of asbestos-related disease, giving voice to the suffering the people of Asbestos could not bring themselves to articulate because of their dependence on the industry. The world now knows that asbestos is deadly, and while Canada was content selling the mineral to developing nations, the rest of the international community was not, once again having an impact on local land in Asbestos.

Years of international shamming campaigns launched against Canada for its continued support of the industry, which included protest marches and demonstrations each year on Canada Day, resulted in a sudden change of plans for the proposed expansion. The voices of these external groups were louder than those of the people in Asbestos. The company cancelled the expansion plan, and both the federal and provincial governments that had been subsidizing the mine withdrew their support. Furthermore, the Canadian Cancer Society, which had previously attempted to suggest that Canadian asbestos was relatively safe, changed its position to more accurately state that all asbestos is dangerous to human health, causing the deaths of approximately 90,000 people each year. ${ }^{44}$

\footnotetext{
44 “Quebec cancer walk nixed over asbestos spat," CBC News, 6 July 2010. http://www.cbc.ca/health/story/2010/07/06/montreal-cp-asbestos-cancels-cancer-walk.html?ref=rss (Accessed 7 July 2010). The Canadian Cancer Society provides financial support, group therapy, and palliative care to many community members dying of asbestos-related cancers.
} 
These recent events have left Asbestos in an uncertain state. After being so central to local identity, even during the massive mine expansion projects townspeople objected to, the land in Asbestos is now frozen, and the community's future appears increasingly finite. This is difficult for a community who's mantra had been that it was a place with a future, not a past, to understand. What remains true in Asbestos today is that the Jeffrey Mine continues to be a viable asbestos mine, if only they could work it, and markets in the developing world continue to seek the mineral, if only they could sell it. These ideas overlook the severe health effects the mineral has on human health, but also highlight an important aspect of resource communities: what happens to these places when the industry they rely on for their livelihood and identity collapses? How does a population reliant on the toxic land they live upon for stability reconcile the harm they do with the only way of life they have ever known? The extended life of the Jeffrey Mine - and the town of Asbestos - is over, and the community is no longer a place with a future, simply a past found at the bottom of a massive open pit mine. 